\title{
Effect of plant density and fertilizer rate on the performance of short duration mustard cv. BARI Sarisha-14
}

\author{
Jannatul Ferdous ${ }^{1 *}$, Chul-Hyun Ahn ${ }^{2 *}$, Md. Shazzadur Rahman ${ }^{1}$, Fakir Muhammad \\ Munawar Hossain ${ }^{2}$ and Ahmed Khairul Hasan
}

\author{
Department of Agronomy, Bangladesh Agricultural University, Mymensingh, Bangladesh \\ ${ }^{3}$ Planning Commission, Government of the People's Republic of Bangladesh \\ "Both authors contributed equally to this manuscript \\ × For any information: ask.author@journalbinet.com \\ Article Received: 20.08.17; Revised: 10.12.17; Published online: 31 December 2017.
} ${ }^{2}$ Department of General Education, Korea National College of Agriculture and Fisheries, Jeonju, Korea

\begin{abstract}
Effect of plant density and fertilizer rate on the performance of short duration mustard $\mathrm{cv}$. BARI Sarisha-14 was investigated with an experiment from October, 2015 to June, 2016 at Agronomy Field Laboratory, Bangladesh Agricultural University, Mymensingh. The experiment was laid out in split plot design with three replications. The experiment consisted of four plant densities: $P_{1}: 56$ plants $/ \mathrm{m}^{2}(30 \mathrm{~cm} \times 6 \mathrm{~cm}), P_{2}: 67$ plants $/ \mathrm{m}^{2}(25 \mathrm{~cm} \times 6 \mathrm{~cm}), P_{3}: 80$ plants $/ \mathrm{m}^{2}(25 \mathrm{~cm} \times 5 \mathrm{~cm}), P_{4}:$ 100 plants $/ \mathrm{m}^{2}(25 \mathrm{~cm} \times 4 \mathrm{~cm})$ and four rates of fertilizer : $F_{0}$ : Control (no fertilizer) $F_{1}: 100 \%$ of fertilizer recommended rate (Fertilizer Recommendation Guide-2012), $F_{2}: 120 \%$ of fertilizer recommended rate $F_{3}: 140 \%$ of fertilizer recommended rate. The highest seed yield was obtained $(1.60 \mathrm{t} / \mathrm{ha})$ in plant density $P_{2}: 67$ plants $/ \mathrm{m}^{2}(25 \mathrm{~cm} \times 6 \mathrm{~cm})$ with the combination of high rates of fertilizer $F_{3}: 140 \%$ of recommended fertilizer rate. The next best result was $(1.50 \mathrm{t} / \mathrm{ha}) \mathrm{recorded}$ in caseof plant density $P_{1}: 56$ plants $/ \mathrm{m}^{2}(30 \mathrm{~cm} \times 6 \mathrm{~cm})$ with the combination of fertilizer rate $F_{3}$ : $140 \%$ of recommended fertilizer rate. It indicated, high plant density with combination of recommended fertilizer reduce yield. It is concluded from the study thatf BARI Sarisha-14 in combination with plant density $(25 \mathrm{~cm} \times 6 \mathrm{~cm})$ and high rates of fertilizer produced highest seed yield at agro- climatic condition of Mymensingh.
\end{abstract}

Key Words: Plant density, Fertilizer, Yield, Mustard and Bari Sarisha-14

Cite Article: Ferdous j., Chul-Hyun A., Rahman, M. S., Hossain, F. M. M. and Hasan, A. K.(2017). Effect of plant density and fertilizer rate on the performance of short duration mustard cV. BARI Sarisha14.Journal of Bioscience and Agriculture Research, 16(01), 1309-1313.

Crossref: https://doi.org/10.18801/jbar.160117.162

Article distributed under terms of a Creative Common Attribution 4.0 International License.

\section{Introduction}

Mustard (Brassica spp.) is one of the most important oilseed crops throughout the world after soybean and groundnut (FAO, 2010). It was originated in southern Europe from where it was introduced to 
Asia and Africa (Downey and Robblene, 1989). Among the mustard producing countries, Canada occupies the first position followed by Nepal, Ukraine and Burma (FAO, 2010). Mustard covers 67\% of the oilseed cropped area producing $56 \%$ of the total oilseed production (BBS, 2011). This quantity can only meet some $30 \%$ the country's edible oil requirements (BBS, 2011). Cultivation of low yielding local varieties, improper plant density and poor fertilizer management are major causes for poor yield of mustard in the country. Production of mustard can be increased by cultivating high yielding varieties. There are many varieties of mustard like Tori-7, Sonil sarisha (SS-75), Kallaynia (TS72), Sampad, Agrani, BARI Sarisha-6, BARI Sarisha-9, BARI Sarisha-12, BARI Sarisha-14, BARI Sarisha-15, SAU Sarisha-1, SAU Sarisha-2. BARI Sarisha-7, BARI Sarisha-8, BARI Sarisha-13, BINA Sarisha-3, BINA Sarisha-4. Among BARI released varieties, BARI sarisha-14 and BARI sarisha-15 are short duration which are cultivated within some 80 days. BARI sarisha-14 is cultivated in the cropping pattern of aman rice-mustard-boro rice. It is also a high yielding variety and farmers can meet their requirements within a very short period of time. Optimum spacing can play an important role in producing higher yield. Proper agronomic manipulation could elevate the yield of mustard. Poor fertilizer management also an important cause for having reduced yield of mustard. Usually, mustard is cultivated in marginal land with low fertility. By supplying proper amount of fertilizer, total production of mustard can be increased. It is reported that application of mixed fertilizers (NPKS) would help to increase seed yield in mustard (Jagvir et al., 2004). The plant density can be adjudged by the use of different doses of fertilizers. A very few research have so far been done with combined application of plant density and fertilizer doses in mustard. Therefore, the present study is undertaken to assess the effect of plant density and fertilizer rate on the performance of recently released mustard cultivar BARI Sarisha-14.

\section{Materials and Methods}

The experiment was conducted at the Agronomy Field Laboratory of the Department of Agronomy, Bangladesh Agricultural University (BAU), Mymensingh, during the period from 2 October, 2015 to 17 January, 2016. The experimental site was a medium high land with well drained clay loam textured soil having $6.9 \mathrm{pH}$ value. The site is located on the sub-tropical zone where temperature is moderately low and plenty of sunshine during Rabi season. BARI Sarisha-14, a new high yielding short duration variety under cruciferae family was used as test crop. Four plant densities viz., 56 plants $/ \mathrm{m}^{2}(30 \mathrm{~cm} \times$ $6 \mathrm{~cm}), 67$ plants $/ \mathrm{m}^{2}(25 \mathrm{~cm} \times 6 \mathrm{~cm}), 80$ plants $/ \mathrm{m}^{2}(25 \mathrm{~cm} \times 5 \mathrm{~cm}), 100$ plants $/ \mathrm{m}^{2}(25 \mathrm{~cm} \times 4 \mathrm{~cm})$ and four rates of fertilizer viz., Control (no fertilizer), $100 \%$ of recommended fertilizer rate (Fertilizer Recommendation Guide-2012) i.e; Urea $=200 \mathrm{~kg} / \mathrm{ha}$, TSP $=130 \mathrm{~kg} / \mathrm{ha}, \mathrm{MoP}=120 \mathrm{~kg} / \mathrm{ha}$, Gypsum= 80 $\mathrm{kg} / \mathrm{ha}$ ), $120 \%$ of recommended fertilizer rate, $140 \%$ of recommended fertilizer rate were used in the experiment. The experiment was laid out in two factor split plot design with three replications. The unit plot size was $1.6 \mathrm{~m} \times 1.25 \mathrm{~m}$. Half of urea and full doses of TSP, MP and gypsum were applied as basal dose during final land preparation. Remaining half urea was applied as top dressing at the time of flower initiation stage ( 25 days after sowing). Hand weeding was done two times at 15 and 30 DAS. Thinning was done in all unit plots with care to maintain a constant plant population in each row. The crop was grown with all other agronomic managements as and when necessary. For the convenience of collecting data, five sample plants/plot were selected at random. The sample plants were uprooted prior to harvest and dried properly in the sun before collecting data. The seed and straw yield/plot were recorded after cleaning and drying them properly in the sun. All the collected data were analyzed with package MSTAT (Russel and Freed, 1986). The mean differences among the treatments were tested with Duncan's Multiple Range Test (Gomez and Gomez, 1984).

\section{Results and Discussion}

Effect of plant density: All the crop characters were significanly influenced by plant densitye (Table 01). Significantly the highest seed yield (1.52 t/ha) was observed in plant density $(25 \mathrm{~cm} \times 6 \mathrm{~cm})$ and the lowest seed yield was $(1.36 \mathrm{t} / \mathrm{ha})$ observed in plant density $(25 \mathrm{~cm} \mathrm{x} 4 \mathrm{~cm})$. Seed yield variation due to different spacing was also observed by Begum (2005) and Alam (2004) in mustard. The highest Stover yield was $(3.23 \mathrm{t} / \mathrm{ha})$ observed in plant density $(25 \mathrm{~cm} \times 6 \mathrm{~cm})$. The lowest stover yield was $(2.90 \mathrm{t} / \mathrm{ha})$ observed in plant density $(25 \mathrm{~cm} \times 5 \mathrm{~cm})$. Number of branches/plant was significantly influenced by different plant density (Table 01). Result revealed that number of branches/plant 
increased with increasing row spacing. The highest number of branches/plant was recorded as 5.0 in plant density $\left(\mathrm{P}_{1}=30 \mathrm{~cm} \times 6 \mathrm{~cm}\right)$ which was significantly greater than others. In contrast, plant density $\mathrm{P}_{4}(25 \mathrm{~cm} \times 4 \mathrm{~cm})$ produced the lowest number of branches/plant (4.25). Similar result was also reported by Oad et al. (2001) in mustard who reported that increased row spacing also increased branch number/plant. Number of siliquae/plant varied significantly due to different plant density. The highest number of siliquae/plant was 52.25 in plant density $\mathrm{P}_{2}(25 \mathrm{~cm} \mathrm{x} 6 \mathrm{~cm})$ and the lowest number of siliquae/plant was 43.25 in both plant density $\mathrm{P}_{3}(25 \mathrm{~cm} \times 5 \mathrm{~cm})$ and $\mathrm{P}_{4}(25 \mathrm{~cm} \mathrm{x} 4 \mathrm{~cm})$.

Table 01. Effect of plant density on plant characters, yield and yield components of short duration Mustard cv. BARI Sarisha-14

\begin{tabular}{|c|c|c|c|c|c|c|c|c|}
\hline $\begin{array}{l}\text { Plant } \\
\text { density }\end{array}$ & $\begin{array}{l}\text { Number } \\
\text { ofbranches } \\
\text { /plant }\end{array}$ & $\begin{array}{l}\text { Number of } \\
\text { siliquae/ } \\
\text { plant }\end{array}$ & $\begin{array}{l}\text { Siliqua } \\
\text { length } \\
(\mathrm{cm})\end{array}$ & $\begin{array}{l}\text { Number } \\
\text { of seeds/ } \\
\text { siliqua }\end{array}$ & $\begin{array}{l}1000-\text { seed } \\
\text { weight }(\mathrm{g})\end{array}$ & $\begin{array}{l}\text { Seed } \\
\text { yield } \\
\text { (t/ha) }\end{array}$ & $\begin{array}{l}\text { Stover } \\
\text { yield } \\
\text { (t/ha) }\end{array}$ & $\begin{array}{l}\text { Biological } \\
\text { yield } \\
\text { (t/ha) }\end{array}$ \\
\hline P1 & $5.00 \mathrm{~b}$ & $48.00 \mathrm{~b}$ & $4.75 b$ & $20.75 b$ & $2.78 \mathrm{~b}$ & $1.46 \mathrm{~b}$ & $3.05 b$ & $4.50 \mathrm{~b}$ \\
\hline $\mathrm{P} 2$ & $6.50 \mathrm{a}$ & $52.25 a$ & $5.45 \mathrm{a}$ & $23.75 a$ & $3.05 a$ & $1.52 \mathrm{a}$ & $3.23 \mathrm{a}$ & $4.75 a$ \\
\hline P3 & $4.50 \mathrm{c}$ & $43.25 c$ & $4.50 \mathrm{c}$ & $20.00 c$ & $2.80 \mathrm{~b}$ & $1.42 \mathrm{~b}$ & $2.90 \mathrm{c}$ & $4.31 c$ \\
\hline $\mathrm{P} 4$ & $4.25 \mathrm{~d}$ & $43.25 c$ & $4.30 \mathrm{~d}$ & $21.25 b$ & $2.68 c$ & $1.36 \mathrm{c}$ & $2.91 c$ & $4.27 c$ \\
\hline LSD 0.05 & 0.12 & 1.32 & 0.14 & 0.71 & 0.09 & 0.05 & 0.09 & 0.12 \\
\hline $\begin{array}{l}\text { Level of } \\
\text { significance }\end{array}$ & $* *$ & $* *$ & $* *$ & $* *$ & $* *$ & $* *$ & $* *$ & $* *$ \\
\hline$C V(\%)$ & 4.02 & 3.03 & 3.37 & 3.54 & 4.21 & 3.12 & 3.95 & 3.01 \\
\hline
\end{tabular}

$*_{* *}^{*}$ Significant at $1 \%$ level of probability; $\mathrm{P}_{1}=30 \mathrm{~cm} \mathrm{x} 6 \mathrm{~cm} ; \mathrm{P}_{2}=25 \mathrm{~cm} \mathrm{x} 6 \mathrm{~cm} ; \mathrm{P}_{3}=25 \mathrm{~cm} \mathrm{x} 5 \mathrm{~cm} ; \mathrm{P}_{4}=25 \mathrm{~cm} \times 4$ $\mathrm{cm}$;

Effect of fertilizer: Different rates of fertilizer significantly influenced the number of seeds/siliqua (Table 02). The number of seeds/siliqua gradually increased with the increasing rates of fertilizer. The highest number of seeds/siliqua (24.75) was obtained with the application of $140 \%$ of recommended fertilizer rate. The lowest number of seeds/siliqua (18.50) was produced by the control treatment. Mondal and Gaffer (1983) observed that different levels of fertilizer dose had significant effect on number of seeds/siliqua. The highest seed yield $(1.50 \mathrm{t} / \mathrm{ha})$ was produced from $140 \%$ of recommended fertilizer rate $\left(F_{3}\right)$. The lowest seed yield $(1.36 \mathrm{t} / \mathrm{ha})$ was found in the control treatment. The cause of yield increment might be due to higher nitrogen consumption and favorable effect of yield contributing characters of mustard. These results are in conformity with that of Mondal and Gaffar (1983), Singh and Rathi (1984), Nang and Singh (1985) who observed increased seed yield of mustard by increasing rate of nitrogen. Application of $140 \%$ of recommended fertilizer rate produced the highest Stover yield (3.22 t/ha) which was significantly different from all other treatments and the control treatment produced the lowest one (2.81 t/ha). Roy et al. (1981) and Kumar and Gangwar (1985) found higher dry Matter and seed yields with $120 \mathrm{~kg} \mathrm{~N} / \mathrm{hair}$ respective of two spp. (B juncea and B. campestris). Thousand seed weight of mustard was significantly affected by different rates of fertilizer dose (Table 02). The highest (2.97 g) 1000- seed weight was found in $140 \%$ of recommended fertilizer rate $\left(\mathrm{F}_{3}\right)$ and the lowest $(2.62 \mathrm{~g}) 1000$-seed weight was found in the control treatment.

Table 02. Effect of fertilizer rate on plant characters, yield and yield components of short duration Mustard cv. BARI Sarisha-14

\begin{tabular}{|c|c|c|c|c|c|c|c|c|}
\hline $\begin{array}{l}\text { Fertilizer } \\
\text { rate }\end{array}$ & $\begin{array}{l}\text { Number of } \\
\text { branches } \\
\text { /plant }\end{array}$ & $\begin{array}{l}\text { Number of } \\
\text { siliquae/ } \\
\text { plant }\end{array}$ & $\begin{array}{l}\text { Siliqua } \\
\text { length } \\
(\mathrm{cm})\end{array}$ & $\begin{array}{l}\text { Number of } \\
\text { seeds/ } \\
\text { siliqua }\end{array}$ & $\begin{array}{l}1000-\text { seed } \\
\text { weight }(\mathrm{g})\end{array}$ & $\begin{array}{l}\text { Seed } \\
\text { yield } \\
\text { (t/ha) }\end{array}$ & $\begin{array}{l}\text { Stover } \\
\text { yield } \\
\text { (t/ha) }\end{array}$ & $\begin{array}{l}\text { Biological } \\
\text { yield } \\
(\mathrm{t} / \mathrm{ha})\end{array}$ \\
\hline F0 & $4.00 \mathrm{~d}$ & $39.50 \mathrm{~d}$ & $4.45 d$ & $18.50 \mathrm{~d}$ & $2.62 c$ & $1.36 \mathrm{c}$ & $2.81 \mathrm{c}$ & $4.17 \mathrm{c}$ \\
\hline $\mathrm{F} 1$ & $5.50 \mathrm{~b}$ & $45.00 \mathrm{c}$ & $4.62 c$ & $20.75 c$ & $2.80 \mathrm{~b}$ & $1.44 \mathrm{~b}$ & $3.00 \mathrm{~b}$ & $4.43 \mathrm{~b}$ \\
\hline $\mathrm{F} 2$ & $5.00 \mathrm{c}$ & $48.75 b$ & $4.87 b$ & $21.75 b$ & $2.90 \mathrm{a}$ & $1.47 \mathrm{ab}$ & $3.05 \mathrm{~b}$ & $4.52 \mathrm{~b}$ \\
\hline F3 & $5.75 a$ & $53.50 \mathrm{a}$ & $5.05 a$ & $24.75 a$ & $2.97 a$ & $1.50 \mathrm{a}$ & $3.22 \mathrm{a}$ & $4.71 \mathrm{a}$ \\
\hline$L S D 0.05$ & 0.17 & 1.19 & 0.14 & 0.64 & 0.10 & 0.38 & 0.10 & 0.11 \\
\hline $\begin{array}{l}\text { Level of } \\
\text { significance }\end{array}$ & $* *$ & $* *$ & $* *$ & $* *$ & $* *$ & $* *$ & $* *$ & $* *$ \\
\hline CV $(\%)$ & 4.02 & 3.03 & 3.37 & 3.54 & 4.21 & 3.12 & 3.95 & 3.01 \\
\hline
\end{tabular}

** = Significant at $1 \%$ level of probability; $\mathrm{F}_{0}=$ Control; $\mathrm{F}_{1}=100 \%$ of fertilizer recommended rate; $\mathrm{F}_{2}=120 \%$ of fertilizer recommended rate; $F_{3}=140 \%$ of fertilizer recommended rate. 
Interaction effect of plant density and fertilizer: All the parameters showed signficant variations due to combined effect of plant density and fertilizer except 1000 seed weight(g). Higher plant height of $82.13 \mathrm{~cm}$ was obtained when higher dose of fertilizer was applied. Lower plant height of $65.53 \mathrm{~cm}$ was found in control dose of fertilizer was applied. Rahman (2003) conducted an experiment on mustard with nitrogen and recorded the highest plant height with the plants treated with $100 \mathrm{~kg} \mathrm{~N} / \mathrm{ha}$ $(79.3 \mathrm{~cm})$, which was about $29.36 \%$ longer than that of the control $(61.3 \mathrm{~cm})$. The data presented in (Table 03) showed that the number of branches/plant significantly influenced by interaction of plant density and fertilizer. The highest number of branches (7.00) was produced from the interaction of plant density $\mathrm{P}_{2}(25 \mathrm{~cm} \times 6 \mathrm{~cm})$ and $140 \%$ recommended fertilizer. A lower number of branches/plant (3.0) was produced by the interaction of plant density $\mathrm{P}_{4}(25 \mathrm{~cm} \times 4 \mathrm{~cm})$ and the control fertilizer. Highest number of siliquae/plant (60.0) was obtained by the combination of plant density $\mathrm{P}_{2}(25 \mathrm{~cm} \mathrm{x}$ $6 \mathrm{~cm}$ ) and 140\% recommendation fertilizer. The lowest number of siliquae/plant (35.00) was obtained by the interaction of plant density $\mathrm{P}_{3}(25 \mathrm{~cm} \mathrm{x} 5 \mathrm{~cm})$ and the control fertilizer. Interaction of plant density and fertilizer doses was significant in respect of number of seeds/siliqua. The highest number of seeds/siliqua (26.0) was obtained in plant density $\mathrm{P}_{2}(25 \mathrm{~cm} \times 6 \mathrm{~cm})$ with highest fertilizer rate $\left(\mathrm{F}_{3}\right)$ and lowest $(17.0)$ was obtained in plant density $\mathrm{P}_{3}(25 \mathrm{~cm} \times 5 \mathrm{~cm})$ with the control treatment of fertilizer.

Plant density coupled with fertilizer rate showed significant effect on seed, stover and biological yields (table 03). The highest seed yield $\left(1.60 \mathrm{t} / \mathrm{ha}\right.$ ) was obtained from the combination of plant density $\mathrm{P}_{2}$ $(25 \mathrm{~cm} \times 6 \mathrm{~cm})$ with $140 \%$ of recommended fertilizer rate $\left(\mathrm{F}_{3}\right)$. The lowest seed yield $(1.20 \mathrm{t} / \mathrm{ha})$ was obtained from the combination of plant density $\mathrm{P}_{4}(25 \mathrm{~cm} \mathrm{x} 4 \mathrm{~cm})$ with the control fertilizer. The highest Stover yield was (3.52) found by the combination of plant density $\mathrm{P}_{2}(25 \mathrm{~cm} \mathrm{x} 6 \mathrm{~cm})$ and the high rate of fertilizer $\left(\mathrm{F}_{3}=140 \%\right.$ of recommended fertilizer rate). The lowest Stover yield was (2.77) observed in the combination of plant density $\mathrm{P}_{4}(25 \mathrm{~cm} \mathrm{x} 4 \mathrm{~cm})$ and the control fertilizer.

Table 03. Interaction effects of plant density and fertilizer rate on plant characters, yield and yield components of short duration Mustard cv. BARI Sarisha-14

\begin{tabular}{|c|c|c|c|c|c|c|c|c|}
\hline $\begin{array}{l}\text { Plant density } \\
\text { x fertilizer } \\
\text { rate }\end{array}$ & $\begin{array}{l}\text { Plant } \\
\text { height } \\
(\mathrm{cm})\end{array}$ & $\begin{array}{l}\text { Number of } \\
\text { branches } \\
\text { /plant }\end{array}$ & $\begin{array}{l}\text { Number of } \\
\text { siliquae/ } \\
\text { plant }\end{array}$ & $\begin{array}{l}\text { Number of } \\
\text { seeds / } \\
\text { siliqua }\end{array}$ & $\begin{array}{l}1000- \\
\text { seed } \\
\text { weight(g) }\end{array}$ & $\begin{array}{l}\text { Seed } \\
\text { yield } \\
\text { (t/ha) }\end{array}$ & $\begin{array}{l}\text { Stover } \\
\text { yield } \\
\text { (t/ha) }\end{array}$ & $\begin{array}{l}\text { Biological } \\
\text { yield } \\
\text { (t/ha) }\end{array}$ \\
\hline P1F0 & 70.30def & $4.00 \mathrm{~d}$ & $40.0 \mathrm{fg}$ & 18.0hi & 2.6 & $1.42 \mathrm{cde}$ & $2.84 \mathrm{~d}$ & $4.26 \mathrm{de}$ \\
\hline P1F1 & $75.0 \mathrm{bcd}$ & $5.00 \mathrm{c}$ & $46.0 \mathrm{de}$ & $20.0 \mathrm{fg}$ & 2.8 & $1.45 \mathrm{cde}$ & $2.99 \mathrm{~cd}$ & $4.44 \mathrm{~d}$ \\
\hline P1F2 & $78.30 \mathrm{bc}$ & $5.00 \mathrm{c}$ & $50.0 c$ & $20.0 \mathrm{fg}$ & 2.8 & $1.48 \mathrm{bcd}$ & $3.00 \mathrm{~d}$ & $4.48 \mathrm{~cd}$ \\
\hline P1F3 & $85.40 \mathrm{a}$ & $6.00 \mathrm{~b}$ & $56.0 \mathrm{~b}$ & $25.0 \mathrm{ab}$ & 2.9 & $1.50 \mathrm{bc}$ & $3.35 \mathrm{ab}$ & $4.85 b$ \\
\hline P2F0 & $65.40 \mathrm{fgh}$ & $5.00 \mathrm{c}$ & $45.0 \mathrm{e}$ & $21.0 \mathrm{ef}$ & 2.8 & $1.43 \mathrm{cde}$ & $2.85 \mathrm{~d}$ & $4.28 \mathrm{de}$ \\
\hline P2F1 & $75.50 \mathrm{bcd}$ & $7.00 \mathrm{a}$ & $50.0 \mathrm{c}$ & $23.0 \mathrm{~cd}$ & 3.0 & $1.50 \mathrm{bc}$ & $3.20 b c$ & $4.70 b c$ \\
\hline $\mathrm{P} 2 \mathrm{~F} 2$ & $86.70 \mathrm{a}$ & $7.00 \mathrm{a}$ & $54.0 \mathrm{~b}$ & $25.0 \mathrm{ab}$ & 3.2 & $1.55 \mathrm{ab}$ & $3.35 \mathrm{ab}$ & $4.90 \mathrm{ab}$ \\
\hline P2F3 & $90.10 \mathrm{a}$ & $7.00 \mathrm{a}$ & $60.0 \mathrm{a}$ & $26.0 \mathrm{a}$ & 3.2 & $1.60 \mathrm{a}$ & $3.52 \mathrm{a}$ & $5.12 \mathrm{a}$ \\
\hline P3F0 & $62.40 \mathrm{~h}$ & $4.00 \mathrm{~d}$ & $35.0 \mathrm{~h}$ & $17.0 \mathrm{i}$ & 2.6 & $1.39 \mathrm{e}$ & $2.78 d$ & $4.17 \mathrm{ef}$ \\
\hline P3F1 & $65.30 \mathrm{fgh}$ & $5.00 \mathrm{c}$ & $42.0 \mathrm{f}$ & $19.0 \mathrm{gh}$ & 2.7 & $1.40 \mathrm{de}$ & $2.89 \mathrm{~d}$ & $4.29 \mathrm{de}$ \\
\hline P3F2 & 70.10def & $4.00 \mathrm{~d}$ & 46.0de & $20.0 \mathrm{fg}$ & 2.9 & $1.42 \mathrm{cde}$ & $2.92 \mathrm{~d}$ & $4.34 \mathrm{de}$ \\
\hline P3F3 & $74.10 \mathrm{bcd}$ & $5.00 \mathrm{c}$ & $50.0 \mathrm{c}$ & $24.0 \mathrm{bc}$ & 3.0 & $1.45 \mathrm{cde}$ & $3.00 \mathrm{~cd}$ & $4.45 \mathrm{~d}$ \\
\hline P4F0 & $64.00 \mathrm{gh}$ & $3.00 \mathrm{e}$ & $38.0 \mathrm{~g}$ & 18.0hi & 2.5 & $1.20 \mathrm{f}$ & $2.77 d$ & $3.97 f$ \\
\hline P4F1 & $68.20 \mathrm{efg}$ & $5.00 \mathrm{c}$ & $42.0 \mathrm{f}$ & $21.0 \mathrm{ef}$ & 2.7 & $1.40 \mathrm{de}$ & $2.92 \mathrm{~d}$ & $4.32 \mathrm{de}$ \\
\hline P4F2 & 72.70cde & $4.00 \mathrm{~d}$ & $45.0 \mathrm{e}$ & $22.0 \mathrm{de}$ & 2.7 & $1.41 \mathrm{de}$ & $2.95 \mathrm{~d}$ & $4.36 \mathrm{de}$ \\
\hline P4F3 & $78.90 \mathrm{~b}$ & $5.00 \mathrm{c}$ & $48.0 \mathrm{~cd}$ & $24.0 \mathrm{bc}$ & 2.8 & $1.44 \mathrm{cde}$ & $3.00 \mathrm{~cd}$ & $4.44 \mathrm{~d}$ \\
\hline$L S D 0.05$ & 5.24 & 0.34 & 2.38 & 1.28 & 0.2 & 0.76 & 0.2 & 0.23 \\
\hline $\begin{array}{l}\text { Level of } \\
\text { significance }\end{array}$ & $*$ & $* *$ & $*$ & $* *$ & $N S$ & * & * & * \\
\hline$C V(\%)$ & 4.21 & 4.02 & 3.03 & 3.54 & 4.21 & 3.12 & 3.95 & 3.01 \\
\hline
\end{tabular}

** = Significant at $1 \%$ level of probability; ${ }^{*}=$ Significant at $5 \%$ level of probability; NS = Not significant $\mathrm{P}_{1}=30 \mathrm{~cm} \times 6 \mathrm{~cm} ; \mathrm{P}_{2}=25 \mathrm{~cm} \times 6 \mathrm{~cm} ; \mathrm{P}_{3}=25 \mathrm{~cm} \times 5 \mathrm{~cm} ; \mathrm{P}_{4}=25 \mathrm{~cm} \mathrm{\times} 4 \mathrm{~cm}$

$\mathrm{F}_{0}=$ Control; $\mathrm{F}_{1}=100 \%$ of fertilizer recommended rate; $\mathrm{F}_{2}=120 \%$ of fertilizer recommended rate; $\mathrm{F}_{3}=140 \%$ of fertilizer recommended rate 


\section{Conclusion}

Plant density $\mathrm{P}_{2}=67$ plants $/ \mathrm{m}^{2}(25 \mathrm{~cm} \times 6 \mathrm{~cm})$ and $140 \%$ of recommended rates of fertilizer were best for BARI Sarisha-14 for highest yield and it should be tested at different Agro-ecological Zones of the country.

\section{Acknowledgement}

The authors gratefully acknowledge the comments and suggestions of Professor Dr. Ahmed Khairul Hasan, Department of Agronomy, Bangladesh Agricultural University, Mymensingh.

\section{References}

[1]. Alam, M. M. (2004). Effect of variety and row spacing on the yield and yield contributing characters of rapeseed and mustard. M. S. Thesis, Department of Agronomy, Bangladesh Agricultural University, Mymensingh. pp.27.

[2]. BBS (Bangladesh Bureau of Statistics) (2011). Statistical Pocket Book of Bangladesh. Statistics Division, Ministry of Plann. Govt. People's Republic of Bangladesh, Dhaka. pp. 212-213.

[3]. Begum, F. (2005). Effect of seed rate and row spacing on the yield and yield components of two varieties of mustard. M. S Thesis, Department of Agronomy, Bangladesh Agricultural University, Mymensingh. pp. 22.

[4]. Downey, R.K. and Robbelen, G (1989). Brassica species. In: Robbenlen, G., Downey, R.K. and A. Astari (eds.) Oil crops of the world. McGrow Hill, New York. P. 339-362.

[5]. FAO (Food and Agriculture Organization), 2010. Production Year Book for 2010. U. N. Rome.

[6]. Gomez, K. A. and Gomez, A. A. (1984). Statistical Procedures Agricultural Research. Wiley, New York, USA. pp. 680.

[7]. Jagvir, S., Monga, D. and Deshmuch, M. S. (2004). Direct and residual effect of sulphur on growth, yield and quality of cotton (Gossypium hirsutum)-mustard (B. juncea) cropping system. Journal of Cotton Research and Development, 18(2), 172-174.

[8]. Kumar, A. and Gangwar, K. S. (1985). Analysis of growth, development and yield of Indian rapeseed (Brassica campestris) in relation to nitrogen and plant density. Indian Journal of Agronomy, 30(3), 358-363.

[9]. Mondal, M. R. I. and M. A. Gaffer (1983). Effect of different levels of nitrogen and phosphorus on the yield and yield contributing characters of mustard. Bangladesh Journal Agriculture Research, 8(1), 37-43.

[10]. Nang, R. S. and Singh, S. (1985). Nitrogen management in Indian mustard. Indian Journal of Agronomy, 30(4), 477-482.

[11]. Oad, F. C., Solangi, B. K., Samo, M. A., Lakho, A. A., Zia-Ul-Hassan and Oad, N. L. (2001\}. Growth, yield and relationship of rapeseed (Brassica napus L.) under different row spacing. International Journal of Agriculture and Biology, 3, 475-476.

[12]. Roy, V., S. Maiti and Chatterjec, B. N. (1981). Growth analysis and fertilizer response of varuna. Indian mustard. Indian Journal of Agricultural Science, 51(3), 173-180.

[13]. Russel, D. and Freed D. (1986). MSTAT-C Package Programme. Crop and Soil Sci. Dept., Michigan Stat. Univ. USA.

[14]. Singh, R. A. and K. S. Rathi (1984). Studies on nitrogen requirement of mustard. Indian Journal of Agronomy, 29(2), 231-233. 